\title{
The accumulation of fluoride by leaves of woody plants growing in the area of sanitary protection zones in the industrial region of Zaporizhzhya
}

\author{
Valentina P. Bessonova, Anastasia V. Sklyarenko $\bowtie$ \\ Dnipro State Agrarian and Economic University, Department of Garden and Park Architecture, S. Efremov 25, Dnipro, \\ 49600, Ukraine, e-mail: s-k2015@ukr.net
}

\begin{abstract}
Vegetation serves as a universal filter that is capable of protecting the environment from pollution by industrial emissions given the availability of appropriate technical facilities. The aim of this study is to determine the ability of leaves of various species of woody plants growing in the area of sanitary protection zones to accumulate fluorine and to establish the most informative indicators of environmental pollution by its compounds. The object of the study was the species of woody plants growing in the area of protective plantations of a number of enterprises of Zaporizhzhya: Zaporizhzhya Titanium \& Magnesium Combine, Zaporizhzhya Aluminium Plant PJSC, Zaporizhzhya Abrasive Plant PJSC, Zaporizhstal PJSC, 'Zaporizhcoke' PJSC (KOKS), Zaporizhzhya Ferroalloy Plant PJSC, Zaporizhvohnetryv ('Vohnetryv') PJSC, PrJSC 'Ukrgrafit' and Zaporizhtransformator PJSC. Under the conditions of sanitary protection zones of enterprises the leaves of woody plants accumulate significantly more fluoride compared to the control specimens. We have established that a gradual accumulation of the element occurs during the vegetation period being the most intense in young leaves. In senescent leaves, the activity of its accumulation begins to diminish. The maximum amount of fluoride was detected by us at the end of the vegetation period. Its highest concentration was found in the leaves of woody plants growing in the forest belt near the Zaporizhzhya Aluminium Plant. According to the level of accumulation of the said phytotoxicant in the leaves of plants growing in the area of sanitary protection zones, industrial enterprises of Zaporizhzhya may be ranked as follows: Zaporizhzhya Aluminium Plant PJSC > Zaporizhzhya Ferroalloy Plant PJSC $\geq$ 'Zaporizhcoke' PJSC $>$ Zaporizhstal PJSC $>$ Zaporizhvohnetryv ('Vohnetryv') PJSC > 'Ukrgrafit' PJSC $>$ Zaporizhzhya Abrasive Plant PJSC $>$ Zaporizhzhya Titanium \& Magnesium Combine $>$ Zaporizhtransformator PJSC. The largest amount of fluorine accumulated by the leaves can be attributed to such tree species as: Catalpa bignonioides, Ailanthus altissima, Acer platanoides, Populus nigra, Armeniaca vulgaris, Tilia cordata, Acer pseudoplatanus, Platanus orientalis, which is a distinguishing characteristic of the sanitary protection zones of various enterprises in the city of Zaporizhzhya. Variations of fluorine accumulation in different experimental plots for the same species of woody plants are expressed in quantitative terms. These plants are capable of being the most efficient at purifying the atmospheric air from gaseous fluoride compounds. The highest coefficient of relative accumulation of fluorine in the leaves is found in the following species of woody plants: Catalpa bignonioides, Ailanthus altissima, Acer platanoides, Populus nigra, Armeniaca vulgaris, Tilia cordata, Acer pseudoplatanus, Platanus orientalis, thus they have a potential to be considered for use as phytoindicators of environmental pollution by the fluorine compounds. The aforementioned coefficient appears to be the lowest in the following species: Morus alba, Elaeagnus angustifolia, Juglans regia and Fraxinus lanceolata.
\end{abstract}




\section{KEY WORDS}

accumulation, fluorine, green plantations, leaves, sanitary protection zones

\section{INTRODUCTION}

Sanitation of atmospheric air contaminated by industrial and automobile emissions remains a global issue in the present-day world. To this end, along with technological methods, the biological method is being used, since the use of even the most advanced filters cannot completely prevent the entry of harmful substances into the environment. The ability of plants to absorb volatile pollutants from the air makes it likely to use them in order to optimize the atmospheric environment, which is the reason green plantations are sometimes being referred to as 'green filters' (Getko 1989; Levon 2014; Wei et al. 2017). Plants act as a kind of buffer that reduce the level of fluctuations in a concentration of airborne pollutants and assist at maintaining the gas balance in the atmosphere (Nowak et al. 2006; Nowak et al. 2018; Sklyarenko and Bessonova 2018), and reduce pollution (Makhelouf 2009, 2013; Simon et al. 2011).

Phytoremediation of atmospheric air is of special importance for large cities with a developed manufacturing sector. The design and normative documents of the Ukrainian state foresee the creation of green spaces in the sanitary protection zones near the enterprises (On Approval of the State Sanitary Rules for Planning and Development of Human Settlements, 1996). Their size depends on the conditions of execution of the operating procedures and the nature and amount of harmful substances released into the environment. It should be noted that the prospect of plants to be used as a means for improving the air quality to an appropriate degree has not yet been studied properly.

Fluorine is one of the most commonly occurring ingredients of industrial emissions. Fluoride is released into the air through man-made emissions of metallurgical and cryolite plants (Vike 1999; Vike 2005), enterprises that produce phosphorus fertilizers (Abdallah et al. 2006), enamel and ceramic products (Fornasiero 2003), glass, bricks, as well as those of coal firing plants (Il'kun 1978; Maning and Feder 1985; Mahadewan et al. 1986). This pollutant is found in the gas form (fluoride F2) of hydrogen fluoride, silicon tetrachloride, as well as in the form of dust particles of sodium and calcium fluorides (Artamanov 1986; Weinstein and Davison 2003; Tandelov 2012).

The accumulation of fluorine is hazardous to the life of plants (Taylor and Basabe 1984; Zimny 1984; Rozhkov and Mikhailova 1989; Prysedskyi 2014; Mondal 2017), causing leaf trauma (necrosis, chlorosis) (Haidouti et al. 1993; Vike and Håbjørg 1995; Fornasiero 2001; Weinstein and Davison 2003; Rhimi et al. 2016). This pollutant negatively affects the growth of trees and the total growth of phytomass (Bunce 1979), promotes the decline in crop yields (Holevas 1988; Szostek and Ciećko 2017). Fluorides are extremely toxic to humans and animals. They also have carcinogenic and mutagenic effects (Perepelenko and Alexanian 1983; Boumah et al. 1984; Belyaiev et al. 1987). This indicates the importance of developing the means of reducing the concentration of these pollutants in the environment using biological methods. There is also a constant need for the discovery of bioindicators for the purpose of biomonitoring of environmental pollution by the fluoride compounds (Weinstein and Davison 2003).

The aim of this study is to determine the ability of leaves of various species of woody plants growing in the area of sanitary protection zones to accumulate fluorine and to establish the most informative indicators of environmental pollution by its compounds.

\section{MAteRial AND METHODS}

Research was carried out in the areas of sanitary protection zones of a number of enterprises in the city of Zaporizhzhya (4749'22" N.L., 35¹1'25» E.L.): Zaporizhzhya Titanium \& Magnesium Combine (ZTMC), Zaporizhzhya Aluminium Plant PJSC (ZALK), «Zaporizhzhya Metallurgical Combine «Zaporizhstal» PJSC (Zaporizhstal), Zaporizhzhya Ferroalloy Plant PJSC (ZFER), which belong to the $1^{\text {st }}$ enterprise hazard class, Zaporizhzhya Abrasive Plant PJSC (ZABR) - $2^{\text {nd }}$, «Vohnetryv-Soyuz PJSC» a.k.a. 'Zaporizhvohnetryv' PJSC (Vohnetryv) - the $3^{\text {rd }}$, «Ukrainian Graphite» PJSC 
(Ukrgrafit), 'Zaporizhtransformator' PJSC (ZTR) $-4^{\text {th }}$. From this point onwards the abbreviated names of these enterprises will be mostly used.

Such enterprises as ZALK, Zaporizhstal, ZFER, Ukrgrafit, Vohnetryv and ZTMC located in the industrial area, forming an industrial complex. The following enterprises are separated from the industrial area by a specified distance: ZTMC (3 km), ZABR $(6 \mathrm{~km})$ and ZTR $(8 \mathrm{~km})$. The control area was assumed to be a forest belt located $12 \mathrm{~km}$ away from the source of pollution.

Woody plants that grew in the areas of sanitary protection zones of all or most enterprises and had large enough share in the plantations were chosen as the objects of our study: Acer negundo L., Acer platanoides L., Acer pseudoplatanus L., Aesculus hippocastanum L., Ailanthus altissima Mill., Armeniaca vulgaris Lam., Betula pendula Roth., Catalpa bignonioides Walter, Elaeagnus angustifolia L., Fraxinus lanceolata Borkh., Juglans regia L., Morus alba L., Platanus orientalis Wiild., Populus alba L., Populus nigra L., Populus piramidalis Borkh., Populus simonii Carr., Robinia pseudoacacia L., Salix alba L., Tilia cordata Mill., Ulmus carpinifolia Rupp., Ulmus laevis Pall. At each site, 5 model trees of a given age category of each species were hand-picked. The leaves needed in order to determine the fluorine content were taken from the southeastern side of the crown at a distance of $2 \mathrm{~m}$ above the soil surface under the identical lighting conditions. The first 3 leaves from the base of one-year shoots were used. The determination of fluorine was conducted by means of the potentiometric method using a fluoroselective electrode as a detector (Khazemova et al. 1983).

Determination of fluorides in the leaves of plants growing in the area of sanitary protection zones of industrial enterprises was carried out while averaging the data by repeating the measurements four times in total. The data obtained was processed according to the generally accepted methods of statistical variation, using ANOVA and Tukey's honest significance test.

\section{Results}

The data obtained from our determining the dynamics of fluorine accumulation in the leaves of Populus nigra and Robinia pseudoacacia under the conditions of the sanitary protection zone of the Zaporizhzhya
Aluminium Plant (ZALK), the emissions of which contain extremely aggressive fluoride compounds (Il'kun 1978; Vike 2005; Mikhailova and Berezhnaya 2000), demonstrate an increase in its amount during the vegetation period (Fig. 1). The rate of accumulation of the element at different stages of leaf ontogenesis is uneven. This process is the most active in young leaves that have already finished growing. As the senescence of leaves approaches, the accumulation of fluorine decreases accordingly. The largest amount of fluorine is detected at the end of the vegetation period, which gives you a certain idea of plants acting as a purifying agent with respect to the said pollutant. In the control specimens, the increase in the amount of pollutant in the leaves during the vegetation period was small. From that point onwards, regarding the leaves of plants in experimental areas, fluorine was determined during the time when its accumulation was the most significant - at the end of the vegetation period.
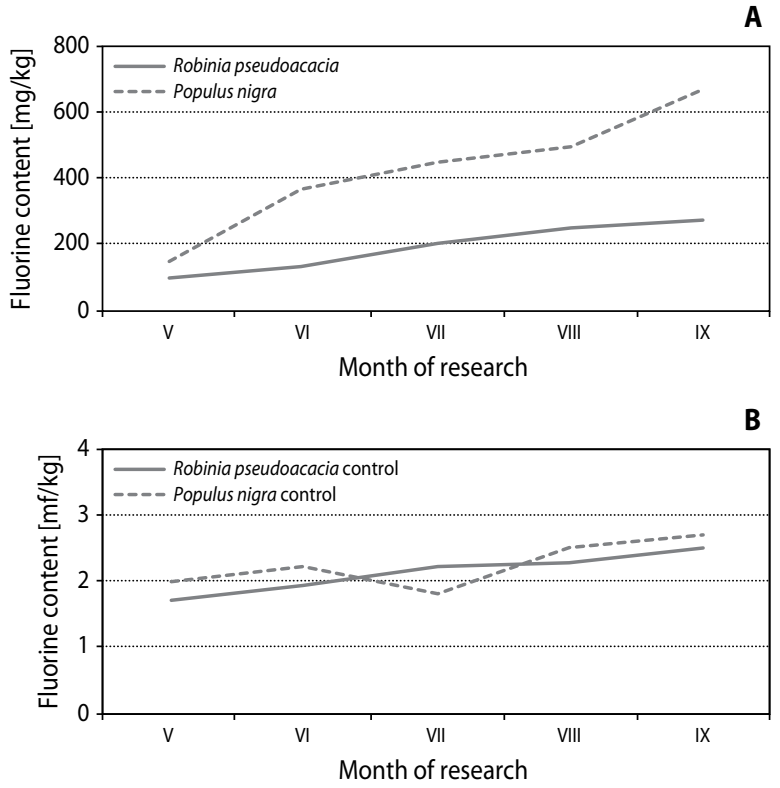

Figure 1. Dynamics of fluorine content in the leaves of woody plants in the area of ZALK sanitary protection zone $(\mathrm{M} \pm \mathrm{m}, \mathrm{n}=4)$

As can be seen from Table 1, the content of fluorine in the leaves of woody plants in a relatively clean zone is insignificant. It varies from 0.98 to $4.98 \mathrm{mg} / \mathrm{kg}$, depending on the species of a plant. The smallest amount of this element is contained in the leaves 


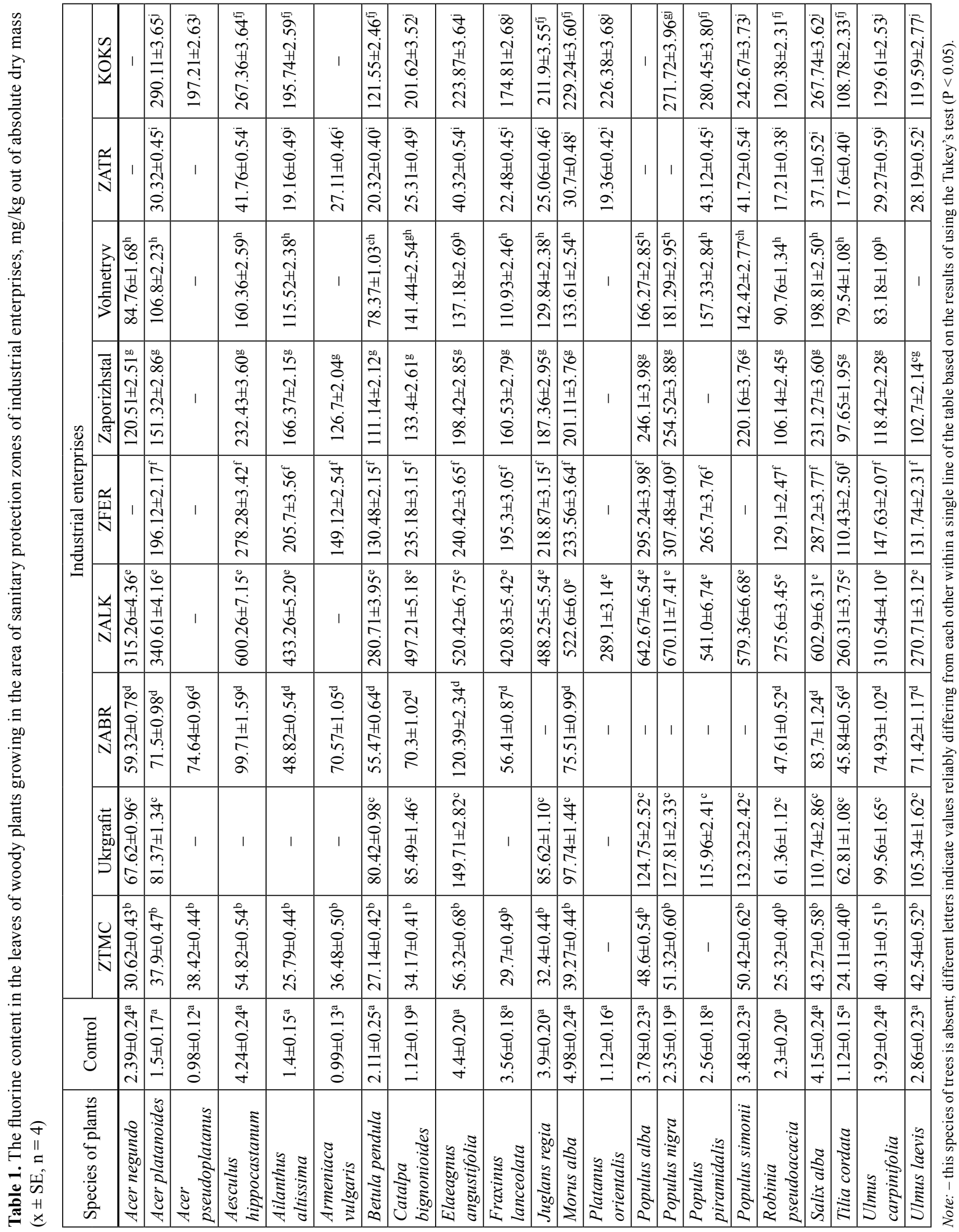



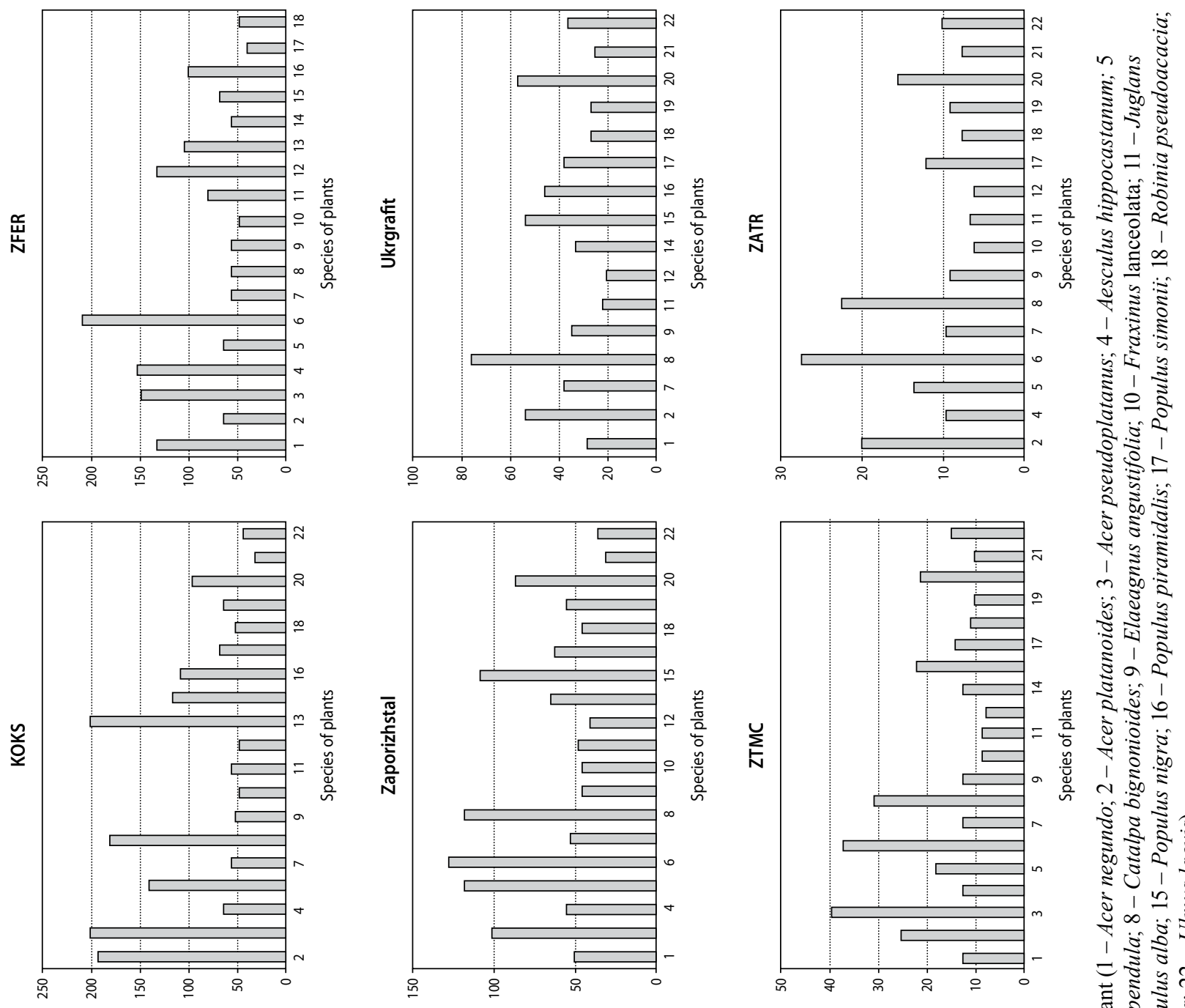

2,0
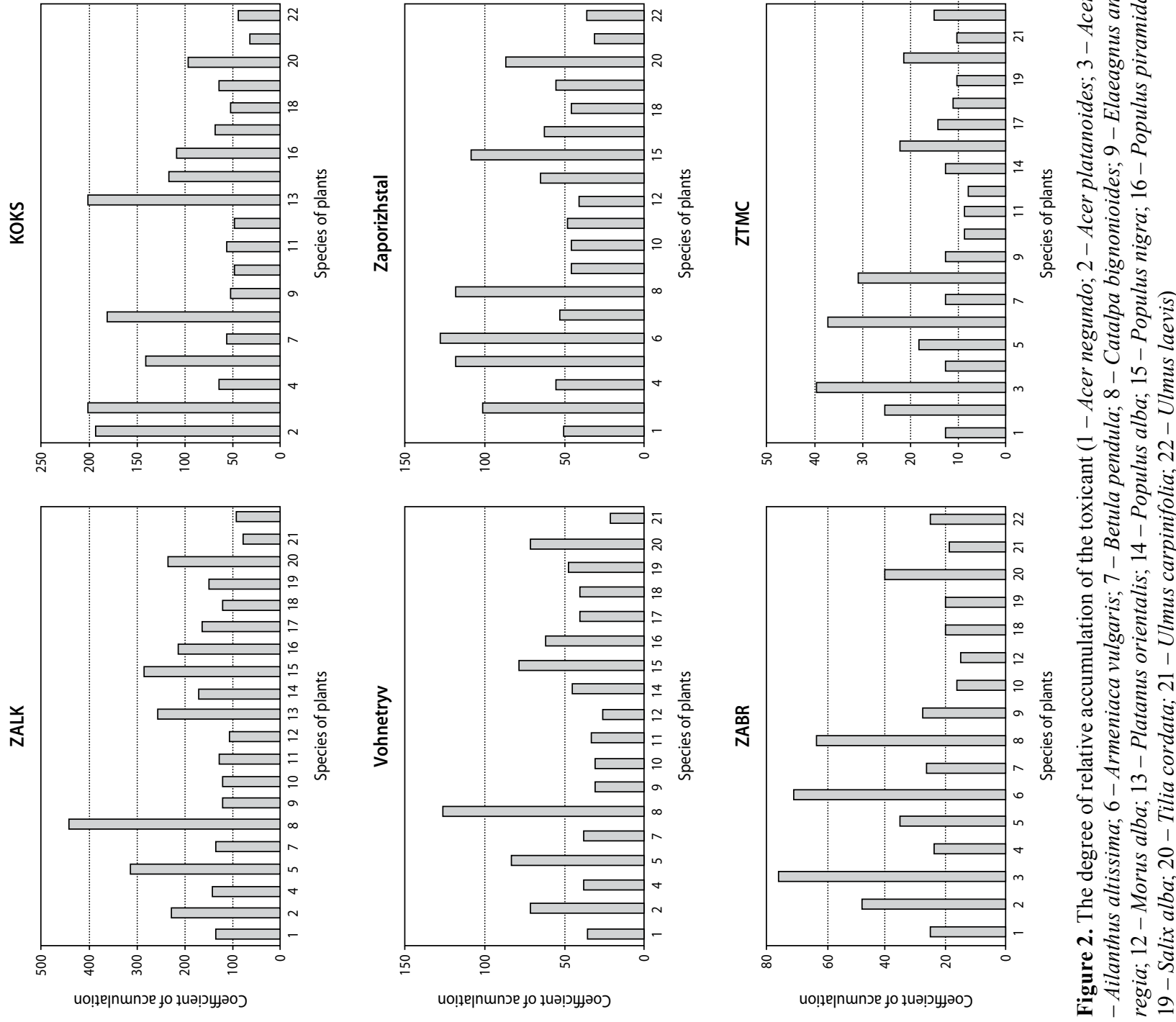
of Acer pseudoplatanus, Armeniaca vulgaris - less than $1 \mathrm{mg} / \mathrm{kg}$ of oven-dry weight. More than $4 \mathrm{mg} / \mathrm{kg}$ is accumulated in Salix alba, Aesculus hippocastanum, Elaeagnus angustifolia, Morus alba.

Under the conditions of sanitary protection zones of enterprises, the leaves of woody plant species accumulate a more significant amount of this element compared to the control. The highest concentrations of fluorine were detected in the organs of assimilation of the trees growing in the area of green plantations of the Zaporizhzhya Aluminium Plant. Figures regarding the fluorine content depend on the species of plants and can vary from 260.31 (Tilia cordata) to 670.11 (Populus nigra) $\mathrm{mg}$ per $\mathrm{kg}$ of oven-dry weight. The smallest amount of this toxicant is accumulated in the leaves of plants in the green zone of the transformer plant. The fluorine levels range from 17.21 (Robinia pseudoacacia) to 43.12 (Populus piramidalis) $\mathrm{mg} / \mathrm{kg}$ of dry weight.

Within the same enterprise concentration of fluorine in leaves of different plant species varies. Characteristically, the largest amount of the element is accumulated in these organs in Populus nigra, Populus alba, Salix alba, Aesculus hippocastanum, Populus piramidalis, Populus simonii. The level of fluorine accumulation in Ailanthus altissima, Fraxinus lanceolata, Catalpa bignonioides, Juglans regia, Morus alba and Elaeagnus angustifolia appears to be very similar among the above-listed species. The least amount of fluorine is accumulated in the leaves of the following plants: Tilia cordata, Ulmus laevis, Robinia pseudoacacia, Platanus orientalis, Betula pendula, Ulmus carpinifolia, Acer negundo, Acer platanoides.

The coefficients of relative accumulation of fluorine by the leaves of woody plant species were calculated - the ratio between values obtained in the sanitary protection zones compared to the ones recorded from the control specimens.

The coefficient of relative accumulation of fluorine in the leaves of plants growing in the area of sanitary protection zones of the Zaporizhzhya Aluminium Plant (ZALK) is the highest in comparison with the other experimental sites. The highest values under the given conditions were found in the following plant species: Catalpa bignonioides, Ailanthus altissima, Populus nigra, Platanus orientalis, Tilia cordata, Acer platanoides. These species possess a rather high, relative to the other plants, coefficient of relative accumulation of the element at such enterprises as: KOKS, ZFER, Vohnetryv, Zaporizhstal and Ukrgrafit.

\section{Discussion}

According to most researchers, fluorine is not a necessary element of plant nutrition; however, in some studies, it is reported that in microdoses of this element can stimulate their growth (Il'kun, 1978). The fluorine content in the tree leaves of the control group, as has already been noted above, is relatively small and does not exceed $4.98 \mathrm{mg} / \mathrm{kg}$ of oven-dry weight. For comparison, the content of fluorides in the aboveground part of plants of the Ukrainian Carpathians totals $0.22-4.14$ and in the underground part $-0.23-3.87 \mathrm{mg} /$ $\mathrm{kg}$ of dry solid mass. In the plain area, this range was wider in the aboveground part comprising 0.15-7.62, and in the underground part, it was $0.1-7.76 \mathrm{mg} / \mathrm{kg}$ of dry solid mass (Kostyshyn et al. 2001). The needles of spruce growing in the territory of Lithuania in areas with atmospheric air free from fluoride compounds contain around $4.9 \mathrm{mg} / \mathrm{kg}$ of fluorine on average (Artamanov 1986). Although a number of studies show significantly higher numbers, the maximum natural fluoride content in plants that grow in nonindustrial areas equals 20-30 mg/kg (Jarkowska 1985; Mezghani et al. 2005). Differences can be explained by different content of fluoride compounds in the soils of investigated areas.

The data concerning the increase in the amount of fluorine in the leaves of Robinia pseudoacacia and Populus nigra, growing in the area of sanitary protection zone of the Zaporizhzhya Aluminium Plant (ZALK), agrees with the results presented in other studies in terms of the vegetation period (Il'kun 1978; Vike 2005).

The increase of atmospheric air pollution at industrial enterprises by the fluorine compounds causes an increase in its amount in the leaves of woody plants compared to the ones growing in a relatively clean zone.

Comparison of the concentration of the element in the leaf mass of the plants under study that grow under the conditions of sanitary protection zones of various enterprises shows significant fluctuations of the said indicator. We found the highest fluorine content in the leaves of plants growing near the Zaporizhzhya Aluminium Plant (ZALK), which is the source of the 
most intense fluorine emissions into the atmosphere (Bunce 1979; Junior et al. 2007).

Significant accumulation of this element in the leaves of plants growing under the anthropogenic conditions is indicated by other authors. Thus, near the aluminium plant, the concentration of fluoride in apricot and grape leaves was $400 \mathrm{mg} / \mathrm{kg}$ (Zuber 1981; Holewas 1988), whereas near the plant that produces phosphate fertilizers $-50 \mu \mathrm{g} / \mathrm{g}$ in apricot, $400 \mu \mathrm{g} / \mathrm{g}$ in olive trees (Mezghani et al. 2005), in the leaves of a number of woody plants - 500-11300 mg/kg (Kluczynski 1983), $138-65 \mathrm{mg} / \mathrm{kg}$ (Vike 2005). The fluoride content in the leaves of ash and fig trees in the area of Annabi (Algeria) amounted to 218 and $298 \mathrm{mg} / \mathrm{kg}$, respectively (Semadi and Cormis 1986). According to Kessabi et al. (1984), the amount of fluorine in plants in contaminated areas ranged from 50 to $1750 \mathrm{mg} / \mathrm{kg}$. Il'kun (1978) discovered a very significant increase in fluorine concentration in the leaf mass of woody plants in the steppe zone of Ukraine in cases of slight damage. Among the seven species of trees under study, the fluorine content varied from 1.06 in Populus nigra to $3.10 \mathrm{~g} / \mathrm{kg}$ dry solid mass in Populus bolleana, which is much larger than in the leaves of plants growing in the area of the sanitary protection zones we are studying.

Evidently, the range of fluorine accumulation, according to a number of researchers, in the area pertaining to the same source of pollution can be quite large. According to our data, the amount of pollutant in the leaves of different plants varies from 260.31 (Tilia cordata) to 670.11 (Populus nigra) mg per kg of dry solid mass in the sanitary protection zone of the Zaporizhzhya Aluminium Plant (ZALK), from 108.78 (Tilia cordata) to 290.11 (Acer platanoides) - in the green plantations of the 'Zaporizhcoke' PJSC (KOKS) and from 110.43 (Tilia cordata) to 307.48 (Populus nigra) $\mathrm{mg} / \mathrm{kg}$ in the forest belt near the Zaporizhzhya Ferroalloy Plant (ZFER). The same applies to the results obtained for trees in other sanitary protection zones. Consequently, the difference in the level of accumulation of fluorine in the leaves of different species of trees within any given sanitary protection zone is less than the one given in some literary sources.

According to the level of accumulation of the said phytotoxicant by the organs of assimilation of trees growing in the area of sanitary protection zones, industrial enterprises of Zaporizhzhya may be ranked as follows:
Zaporizhzhya Aluminium Plant PJSC $>$ Zaporizhzhya Ferroalloy Plant PJSC $\geq$ 'Zaporizhcoke' PJSC > Zaporizhstal PJSC > Zaporizhvohnetryv ('Vohnetryv') PJSC $>$ 'Ukrgrafit' PJSC $>$ Zaporizhzhya Abrasive Plant PJSC $>$ Zaporizhzhya Titanium \& Magnesium Combine $>$ Zaporizhtransformator PJSC.It has been proven that the phytotoxic level of fluorine in the aboveground parts of plants increases mainly due to its pollution by atmospheric fluorine compounds. It is also known that the accumulation of fluorine has a dose-dependent nature (Taylor and Bassabe 1984; Zimny 1984; Lorenzini et al. 1987; Prysedskyi 2014). With the fall of the level of atmospheric air pollution by fluorine, its content in the leaves of woody plants decreases (Mezghani et al. 2005). And the work of Mikhailova and Berezhnaya (2000) indicates the direct dependence of the content of fluorides in the needles of common pine on the number of fluorine-containing ingredients (hydrogen fluoride and solid fluorides) in emissions, which is confirmed by the calculation of the correlation coefficients between these parameters. Consequently, according to the results pertaining to the fluorine accumulation in the tree leaves in our experiment, it can be assumed that out of all the areas investigated, the air was most polluted in the sanitary protection zone near the Zaporizhzhya Aluminium Combine (ZALK), while the area near the Zaporizhtransformator PJSC (ZTR) was the least polluted one.

Plants that accumulate more of this pollutant are best at purifying the atmospheric air. While having a discussion concerning their role as a purifying agent, it should be noted that, unlike phenol, according to a number of researchers, fluorides are not metabolized at all and do not move from one organ to the other; their detoxification in the plant cell does not occur at all (Jacobson et al. 1966; Banerjee and Roychoudhury 2019). No movement of fluorides from older leaves to younger ones was found either in broad beans or in kale (Guderian 1979), as well as from the apical to basal areas of the crown of spruce (Rozhkov and Mikhailova 1989). However, Vike (2005) indicates that fluoride is washed away from plant leaves under the influence of rain. Jacobson et al. (1966) also indicate that irreversible binding to cellular components does not occur. These results indicate the possibility of loss by the leaves of a certain amount of fluorides accumulated in them.

Species with high relative accumulation of fluorine have the capacity to be the most effective at purifying 
the environment under the conditions of technogenic landscapes. In order to do so, they ought to be able to combine the tolerance to high toxicant levels with higher resistance to leaf damage. As has already been noted above, such plants as Populus nigra, Populus alba, Salix alba, Aesculus hippocastanum, Populus pyramidalis, Populus simonii can be considered to satisfy the aforementioned criteria.

The main link in a chain of identifying the environmental quality is the long-term monitoring of the most toxic and widespread pollutants, notably fluorides. The basis for selecting a plant for the purpose of monitoring is the correspondence between the level of atmospheric air pollution, fluorides and their level of accumulation. Such an indicator of accumulation of an element is the ratio of relative accumulation, which expresses the dependence of its content in the leaves of plants under the conditions of environmental pollution compared to its background level. It allows us to compare the degree of the rise of the level of accumulation of an element in various species of plants under the conditions of technogenic pollution of the environment. That is why, this value is indicative as a criterion for assessing the suitability of a species for passive monitoring of environmental pollution by toxic elements.

It should be noted that some agricultural plants have been identified as bioindicators for the purpose of analysing the degree of atmospheric air pollution by fluorides (Banerjee and Roychoudhury 2019). According to a study by Vike (1999), the best species for monitoring the atmospheric fluorine is Sorbus aucuparia (on the basis of leaf analysis).

The comparison of the coefficients of fluorine accumulation calculated for the assimilation organs of different species of woody plants shows that the best bioindicators of environmental pollution by said toxicant are Catalpa bignonioides, Ailanthus altissima, Acer platanoides, Populus nigra, Armeniaca vulgaris, Tilia cordata, Acer pseudoplatanus, Platanus orientalis.

\section{Conclusions}

The accumulation of fluorine in the leaves of woody plants growing in the area the sanitary protection zones of the industrial region of Zaporizhzhya occurs during the entire vegetation period, being the most intense in young leaves that have finished growing. The maximum amount of element is detected at the end of the vegetation period.

Under the conditions of sanitary protection zones of enterprises the leaves of woody plants accumulate significantly more fluorine compared to the control group. Its highest concentrations were found in the leaves of woody plants near the Zaporizhzhya Aluminium Combine (ZALK). According to the level of accumulation of said phytotoxicant in the leaves of plants growing in the area of sanitary protection zones, industrial enterprises of Zaporizhzhya may be ranked as follows: Zaporizhzhya Aluminium Plant PJSC $>$ Zaporizhzhya Ferroalloy Plant PJSC $\geq$ 'Zaporizhcoke' PJSC $>$ Zaporizhstal PJSC > Zaporizhvohnetryv ('Vohnetryv') PJSC $>$ 'Ukrgrafit' PJSC $>$ Zaporizhzhya Abrasive Plant PJSC $>$ Zaporizhzhya Titanium \& Magnesium Combine > Zaporizhtransformator PJSC.

Species of trees that accumulate the largest amount of fluorine in their leaves are as follows: Catalpa bignonioides, Ailanthus altissima, Acer platanoides, Populus nigra, Armeniaca vulgaris, Tilia cordata, Acer pseudoplatanus, Platanus orientalis, which is a distinguishing characteristic of sanitary protection zones of various enterprises in the city of Zaporizhzhya. The differences between experimental plots for the same species of woody plants were expressed in quantitative terms. These plants have the capacity to be the most efficient at purifying the atmospheric air from gaseous fluoride compounds.

The highest coefficient of relative accumulation of fluorine by the leaves is found in such species of plants as: Catalpa bignonioides, Ailanthus altissima, Acer platanoides, Populus nigra, Armeniaca vulgaris, Tilia cordata, Acer pseudoplatanus, Platanus orientalis, thus they have a potential to be considered for use as phytoindicators of environmental pollution by the fluorine compounds. The aforementioned coefficient appears to be the lowest in the following species: Morus alba, Elaeagnus angustifolia, Juglans regia and Fraxinus lanceolata.

The results obtained can be used for the development of recommendations for the selection of assortment of woody plants for the purpose of reconstruction of green plantations in the area of sanitary protection zones of enterprises. 


\section{ReferenCES}

Abdallah, F.B., Elloumi, N., Mezghani, I., Boukhris, M., Garrec, J.-P. 2006. Survival strategies of pomegranate and almond trees in a fluoride polluted area Stratégies de survie du grenadier et de l'amandier dans une zone à pollution fluorée. Comptes Rendus Biologies, 329 (3), 200-207. DOI: 10.1016/j.crvi.2005.12.003

Artamanov, V.I. 1986. Plants and purity of the natural environment (in Russian). Naukova dumka, Moscow.

Banerjee, A., Roychoudhury, A. 2019. Fluorine: abiohazardous agent for plants and phytoremediation strategies for its removal from the environment. Biologia Plantarum, 63, 104-112. DOI: 10.32615/ bp.2019.013

Belyaiev, I.Ya., Ivanksheva, M.Yu., Akifyev, A.P. 1987. Reproduction in the second nuclear cycle of chromatid aberrations induced in Crepis capillaris cells by neutrons and 5-fluoro-2 deoxyuridine (in Russian). Reports of the Academy of Sciences of the USSR, 252 (1), 227-230.

Boumah, C.E., Setterfield, G., Kaplan, J.G. 1984. Purine and pyrimidine analogues irreversibly prevent passage of lymphocytes from the $\mathrm{G} 1$ to the $\mathrm{S}$ phase of the cell cycle. Biochemistry and Cell Biology, 62 (5), 280-287. DOI: 10.1139/o84-039

Bunce, H.W.F. 1979. Fluoride Emissions and Forest Growth. Journal of the Air Pollution Control Association, 29 (6), 642-643. DOI: 10.1080/00022 470.1979.10470839

Fornasiero, R.B. 2003. Fluorides effects on Hypericum perforatumplants: first field observations. Plant Science, 165 (3), 507-513. DOI: 10.1016/S01689452(03)00205-X

Fornasiero, R.B. 2001. Phytotoxic effects of fluorides. Plant Science, 161 (5), 979-985. DOI: 10.1016/ S0168-9452(01)00499-X

Getko, N.V. 1989. Plants in an industrial environment (in Russian). Nauka i Tehnika, Minsk.

Guderian, R. 1979. Air pollution (in Russian). Mir, Moscow.

Haidouti, C., Chronopoulou, A., Chronopoulos, J. 1993. Effects of fluoride emissions from industry on the fluoride concentration of soils and vegetation.
Biochemical Systematics and Ecology, 21 (2), 195-208. DOI:10.1016/0305-1978(93)90037-R

Holevas, C.D. 1988. Airborne Pollutant Injury to Vegetation in Greece. Air Pollution and Ecosystems, 154-157. DOI: 10.1007/978-94-009-4003-1_18

Il'kun, G.V. 1978. Plants and outdoor air pollutants (in Russian). Naukova dumka, Kiev.

Jacobson, J.S., Weinstein, L.H., Mccune, D.C., Hitchcock, A.E. 1966. The Accumulation of Fluorine by Plants. Journal of the Air Pollution Control Association, 16 (8), 412-417. DOI: 10.1080/00022470.1966.10468494

Jarkowska, H. 1985. Zawartość i rozmieszczenie fluoru w roślinach. Zeszyty Naukowe Akademii Rolniczej w Krakowie. Sesja Naukow, 3, 107-124.

Junior, A.M.D., Oliva, M.A., Martinez, C.A., Cambraia, J. 2007. Effects of fluoride emissions on two tropical grasses: Chloris gayana and Panicum maximum cv. Colonião. Ecotoxicology and Environmental Safety, 67 (2), 247-253. DOI: 10.1016/j.ecoenv.2006.06.002 Khazemova, L.A., Radovskaya, T.L., Kruglova, N.V., Kachalkova, T.K. 1983. Determination of fluoride content in plant material (in Russian). Agrochemistry, 6, 66-72.

Kessabi, M., Assimi, B., Braun, J.P. 1984. The effects of fluoride on animals and plants in the South Safi zone. Science of The Total Environment, 38, 63-68. DOI: 10.1016/0048-9697(84)90208-0

Kluczyński, B. 1983. Tolerancja drzew i krzewów na działanie wysokich stężeń zwiąków fluoru w warunkach huty aluminium Konin. Arboretum Kórnickie, 27, 235-264.

Kostyshyn, S.S., Perepelitsa, O.O., Smetanyuk, O.I. 2001. Peculiarities of fluoride accumulation in plants of meadow biotopes of Northern Bukovina (in Russian). Sibirskiy Ekologicheskiy Zhurnal, 6, 843-849.

Levon, F.M. 2014. Green plantations in an anthropogenically transformed environment (in Russian). Institute of Agrarian Economics, Kiev.

Lorenzini, G., Panattoni, A., Guidi, L. 1987. Ricerche sugli effetti fitotossici dei fluoruri atmosferici nei dintomi di una sorgente industriale. Informatore Fitopatologico, 37 (3), 41-48.

Mahadevan, T.N., Meenakshy, V., Mishra, U.C. 1986. Fluoride cycling in nature through precipitation. 
Atmospheric Environment (1967), 20 (9), 1745-1749.

DOI: 10.1016/0004-6981(86)90123-X

Makhelouf, A. 2009. The Effect Of Green Spaces On Urban Climate And Pollution. Iranian Association of Environmental Health, 6 (1), 35-40.

Makhelouf, A. 2013. The contribution of the urban green spaces in the regulation of the microclimate and the improvement of the air quality in cities. Asian Journal of Current Engineering and Maths, 2, 190-195.

Manning, U.Dzh., Feder U.A. 1985. Biomonitoring of air pollution using plants (in Russian). Gidrometeoizdat, Leningrad.

Mezghani, I., Elloumi, N., Abdallah, F.B., Chaieb, M., Boukhris, M. 2005. Fluoride accumulation by vegetation in the vicinity of a phosphate fertilizer plant in Tunisia. Fluoride, 38 (1), 69-75.

Mikhailova, T.A., Berezhnaya, N.S. 2000. Assessment state of pine forests under the long-term impact of emissions from an aluminium plant (in Russian). Geography and Natural Resources, 1, 43-50.

Mondal, N.K. 2017. Effect of fluoride on photosynthesis, growth and accumulation of four widely cultivated rice (Oryza sativa L.) varieties in India. Ecotoxicology and Environmental Safety, 144, 36-44. DOI: 10.1016/j.ecoenv.2017.06.009

Nowak, D.J., Crane, D.E., Stevens, J.C. 2006. Air pollution removal by urban trees and shrubs in the United States. Urban Forestry and Urban Greening, 4 (3/4), 115-123. DOI: 10.1016/j.ufug.2006.01.007

Nowak, D.J., Hirabayashi, S., Doyle, M., McGovern, M., Pasher, J. 2018. Air pollution removal by urban forests in Canada and its effect on air quality and human health. Urban Forestry and Urban Greening, 29, 40-48. DOI: 10.1016/j.ufug.2017.10.019

On Approval of State Sanitary Rules for Planning and Development of Human Settlements. Annex No 4. 1996. No 173. (in Ukrainian). Available at http:// search.ligazakon.ua/1_doc2.nsf/link1/REG1404. html

Perepelenko, S.D., Aleksanian, A.K. 1983. Influence of cotoran (fluometuron) and sodium fluoride on nucleic acids and the frequency of chromosomal aberrations in the cells of cotton roots (in Russian). Vliyanie mutagenov sredyi na selskohozyaystvennyie rasteniya. Samarhaid, 27-32.
Prysedskyi, Yu.G. 2014. The characteristic of the resistance of woody and bushy plant to air pollution by sulfur, fluorine and nitrogen compounds (in Ukrainian). The Journal of V.N. Karazin Kharkiv National University. Series Biology, 21, 162-167.

Rhimi, N., Ben Ahmed, C., Elloumi, N., Athar, H.R., Noreen, S., Ashraf, M., Ben Abdallah, F., Ben Nasri-Ayachi, M. 2016. Morpho-anatomical and physiological changes in grapevine leaves exposed to atmospheric fluoride and sulfur dioxide pollution. Applied Ecology and Environmental Research, 14 (5), 77-89. DOI: 10.15666/aeer/1405_077089

Rozhkov, A.S., Mikhailova, T.A. 1989. The action of the fluorine-containing emissions on conifers (in Russian). Nauka, Novosibirsk.

Semadi, A., De Cormis, L. 1986. Influence de la pollution atmospherique fluoree sur la vegetation de la region d'Annaba (Algerie). Pollution Atmosphérique, 1-3, 24-30.

Simon, E., Braun, M., Vidic, A., Bogyó, D., Fábián, I., Tóthmérész, B. 2011. Air pollution assessment based on elemental concentration of leaves tissue and foliage dust along an urbanization gradient in Vienna. Environmental Pollution, 159 (5), 1229-1233. DOI: 10.1016/j.envpol.2011.01.034

Sklyarenko, A.V., Bessonova, V.P. 2018. Accumulation of sulfur and glutathione in leaves of woody plants growing under the conditions of outdoor air pollution by sulfur dioxide. Biosystems Diversity, 26 (4), 334-338. DOI: 10.15421/011849

Szostek, R., Ciećko, Z. 2017. Effect of soil contamination with fluorine on the yield and content of nitrogen forms in the biomass of crops. Environmental Science and Pollution Research, 24 (9), 8588-8601. DOI: 10.1007/s11356-017-8523-6

Tandelov, Yu.P. 2012. Fluorine in the soil-plant system (in Russian). Krasnoyarsk.

Taylor, R.J., Basabe, F.A. 1984. Patterns of fluoride accumulation and growth reduction exhibited by Douglas fir in the vicinity of an aluminium reduction plant. Environmental Pollution Series A, Ecological and Biological, 33 (3), 221-235. DOI: 10.1016/0143-1471(84)90012-6

Vike, E. 1999. Air-pollutant dispersal patterns and vegetation damage in the vicinity of three aluminium smelters in Norway. Science of the 
Total Environment, 236 (1/3), 75-90. DOI: 10.1016/ S0048-9697(99)00268-5

Vike, E. 2005. Uptake, deposition and wash off of fluoride and aluminium in plant foliage in the vicinity of an aluminium smelter in Norway. Water, Air, and Soil Pollution, 160 (1/4), 145-159. DOI: $10.1007 / \mathrm{s} 11270-005-3862-1$

Vike, E., Håbjørg, A. 1995. Variation in fluoride content and leaf injury on plants associated with three aluminium smelters in Norway. Science of the Total Environment, 163 (1/3), 25-34. DOI: 10.1016/00489697(95)04497-O

Wei, X., Lyu, S., Yu, Y., Wang, Z., Liu, H., Pan, D., Chen, J. 2017. Phylloremediation of air pollutants: exploiting the potential of plant leaves and leaf- associated microbes. Frontiers in Plant Science, 8, 13-18. DOI: 10.3389/fpls.2017.01318

Weinstein, L.H., Davison, A.W. 2003. Native plant species suitable as bioindicators and biomonitors for airborne fluoride. Environmental Pollution, 125 (1), 3-11. DOI: 10.1016/S0269-7491(03)00090-3

Zimny, H. 1984. Ecological effects of industrial pollutants and their effect on cultivated plants. Studies in Environmental Science, 23, 79-91. DOI: 10.1016/S0166-1116(08)71218-4

Zuber, R., Tschannen, W., Bovay, E. 1981. Contrôle de la teneur en fluor des feuilles d'abricotiers de la vallée du Rhône de 1974 à 1980. Revue suisse. Vitic. Arboric. Hortic, 13 (3), 131-138. 